\title{
Om Claude Lefort
}

Claude Lefort, født 1924, er filosof og ansat ved Ecole des Hautes Etudes en Sciences Sociales (EHESS). Leforts interesse for politikkens felt stammer helt tilbage fra ungdomsårene, hvor han som aktiv trotskist bl.a. deltog i diskussionerne omkring det sovjetiske samfunds karakter. Han brød dog allerede i 1948 med den trotskistiske bevægelse omkring IV. Internationale og grundlagde bl.a. sammen med den fra Grækenland flygtede Cornelius Castoriadis gruppen og tidsskriftet Socialisme ou barbarie, der i 1950 'erne udviklede sig til et vigtigt forum for kritikken af stalinismen og for en kritisk Marx-læsning uden for kommunistpartiets dogmatik. I dette tidsskrift udfoldede Lefort de analyser af det sovjetiske bureaukratis position og rolle, der senere skulle føre ham frem til en generel teori om den totalitære samfundsform. Artiklerne herfra har han udgivet i Eléments d'une critique de la bureaucratie (Paris: Droz 1971).

Sideløbende med sit engagement i Socialisme ou barbarie har Lefort været optaget af generelle temaer inden for politisk filosofi og antropologi. Mest kendt er han nok for sit monumentale Machiavelli-studie fra 1972 Le travail de l'oeuvre, Machiavel (Paris: Gallimard). Men han har tillige i talrige artikler behandlet både den Marx'ske teori og klassikere inden for antropologien som Mauss og Bateson. En række af disse er samlet i Les formes de l'histoire (Paris: Gallimard 1978), som Lefort forsynede med undertitlen Essais d'anthropologie politique.

I 1970'erne har Lefort især beskæftiget sig med forholdet mellem totalitarisme og demokrati. Det var i denne periode, at han udformede sin teori om den demokratiske samfundsform. En teori, som for alvor blev præsenteret i bogen Un homme en trop (Paris: Seuil 1976), der former sig som en lang kommentar til Solsjenitzins $\emptyset$ havet Gulag. Gennem studier af politiske tænkere som Tocqueville og Hannah Arendt har Lefort arbejdet videre med denne problemstilling. Disse studier er især blevet præsenteret $\mathrm{i}$ idsskriftet Libre, som Lefort sammen med folk som Castoriadis, antropologen Pierre Clastres og Marcel Gauchet startede i 1977 (det ophørte i 1980). De fleste af artiklerne fra slutningen af 1970'erne er samlet i Leforts to seneste udgivelser L'Invention démocratique (Paris: Fayard 1981) og Essais sur le politique. XIXe-XXe siecles (Paris: Seuil 1986). På det seneste har han kastet sin interesse på det 19. århundredes franske, politiske tænkere som Benjamin Constant, Edgar Quinet, Michelet og ikke mindst Tocqueville.

Leforts teoretiske inspiration kommer ikke mindst fra hans beskæftigen sig med Marx og Machiavelli. Men hans filosofiske læremester er og bliver Maurice MerleauPonty (1908-1961), som han blev knyttet til allerede i gymnasieårene under krigen, og som han arbejdede sammen med i den legendariske redaktion af Les temps modernes i begyndelsen af 1950 'erne. Indflydelsen fra Merleau-Pontys filosofi lader sig aflæse i alle Leforts arbejder. Således er Lefort stærkt influeret af såvel den generelle fænomenologiske problematik, Merleau-Ponty udformede, som hans politiskfilosofiske tænkning, som den især kommer til udtryk i Les aventures de la dialectique fra 1956. Det var heri Merleau-Ponty dels gjorde op med den marxistiske historiefilosofi, dels rettede en heftig kritik mod Sartres politiske program. Med de posthume Mer- 
leau-Ponty udgivelser, Lefort har foranlediget, har han nærmest fåt status af officiel forvalter af den Merleau-Ponty'ske arv. Han har dog selv kun ganske lidt beskæftiget sig med de filosofiske grundspørgsmål, der interesserede Merleau-Ponty. I 1978 udgav han en samling artikler om Merleau-Ponty under titlen Sur une colonne absente (Paris: Gallimard).

Jan Ifversen 